БОЛЬШАКОВА Валентина Михайловна - кандидат юридических наук, доцент; заведующий кафедрой конституционного и муниципального права Нижегородского института управления - филиала Российской академии народного хозяйства и государственной службы при Президенте РФ (603009, Россия, г. Нижний Новгород, пр-кт Гагарина, 46)

\title{
КОНСТИТУЦИОННАЯ ОСНОВА СТРАТЕГИЧЕСКИХ ЗАДАЧ МУНИЦИПАЛЬНОЙ СЛУЖБЫ
}

Аннотация. В статье дается обоснование стратегических задач муниципальной службы в условиях реформирования и развития местного самоуправления. Автор показывает необходимость постановки органами местного самоуправления стратегических задач аппарату муниципальной службы.

Ключевые слова: муниципальная служба, конституционные задачи органов местного самоуправления и их аппарата, обеспечение полномочий

$\mathrm{K}$ онституция РФ 1993 г. положила начало продолжительному и многосложному процессу реформирования местного самоуправления на основе всестороннего развития его правовой основы. Несмотря на то что в Конституции РФ понятийный аппарат, относящийся к муниципальной службе, не был использован, в ст. 72 содержится принципиально важное указание для федерального и регионального законодателей, косвенно имеющее отношение к муниципальной службе. В частности, анализ пунктов «К» и «н» ч. 1 указанной статьи позволяют сделать вывод, что правовое регулирование муниципальной службы отнесено Конституцией РФ к совместному ведению Российской Федерации и субъектов в ее составе, ибо к совместному ведению в пункте «к» отнесена такая отрасль российской правовой системы, как трудовое законодательство, а именно трудовое право непосредственно регулирует муниципально-служебные отношения, а в пункте «н» к совместному ведению отнесено «установление общих принципов организации системы органов государственной власти и местного самоуправления», имеющих непосредственное отношение к деятельности как государственного, так и муниципального аппарата. Методологическое значение для организации муниципальной службы имеет также указание ст. 12 Конституции РФ на то, что органы местного самоуправления не входят в систему органов государственной власти. Из этого следует, что и муниципальный аппарат (муниципальная служба) органов местного самоуправления также не должен входить в систему государственного аппарата (государственной службы РФ).

Вот почему реформа местного самоуправления, которая начала разворачиваться в стране в начале нулевых годов, не могла не затронуть и муниципальную службу. Становилось очевидным, что федеральные законы о местном самоуправлении 1995 г. и о муниципальной службе 1998 г. уже не отвечали требованиям времени. Сначала 6 октября 2003 г. принимается новая редакция федерального закона «Об общих принципах организации местного самоуправления в Российской Федерации» № 131-Ф3, а затем 2 марта 2007 г. - федеральный закон «О муниципальной службе в Российской Федерации» № 25-Ф3. Глубинная взаимосвязь указанных федеральных законов обусловлена предназначением муниципальной службы - обеспечить полномочия местного самоуправления, которыми муниципальные органы власти наделяются федеральным законом в целях решения вопросов местного значения. 
Органы местного самоуправления, олицетворяющие политическую власть, по отношению к муниципальному аппарату, осуществляющему власть административную, призваны направлять его деятельность, формулируя стоящие перед ними общие стратегические задачи, которые определяются, с одной стороны, требованиями Конституции РФ и принимаемыми в соответствии с ней федеральными законами, а с другой - спецификой и потенциальными возможностями социально-экономического развития территорий муниципальных образований. Постановка стратегических задач деятельности аппарата органов местного самоуправления, на наш взгляд, позволит конкретизировать профессиональную служебную деятельность муниципальных служащих и добиться качественных изменений в социально-экономическом и культурном развитии территорий, в удовлетворении повседневных нужд населения муниципальных образований.

Очевидно, существует динамика стратегических задач, выдвигаемых перед муниципальной службой по мере реформирования и развития местного самоуправления. При этом ключевыми (базовыми) задачами деятельности органов местного самоуправления и их аппарата, непосредственно вытекающими из требований Конституции РФ, всегда остаются следующие:

1) обеспечение прав и свобод человека и гражданина на территории муниципального образования: «Права и свободы человека и гражданина являются непосредственно действующими. Они определяют смысл, содержание и применение законов, деятельность законодательной и исполнительной власти, местного самоуправления и обеспечиваются правосудием» (ст. 18);

2) оптимизация социально-экономических и иных условий жизнедеятельности населения, удовлетворение его повседневных потребностей, прежде всего в сферах:

- организации предоставления общедоступного и бесплатного дошкольного, начального общего, основного общего, среднего общего образования по основным общеобразовательным программам в муниципальных образовательных организациях;

- создания условий для оказания медицинской помощи населению на территории муниципального образования в соответствии с территориальными программами государственных гарантий бесплатного оказания гражданам медицинской помощи;

- обеспечения правомочий органов местного самоуправления по владению, пользованию и распоряжению муниципальным имуществом;

- создания условий для обеспечения муниципальных образований услугами связи, общественного питания, торговли и бытового обслуживания.

Эта стратегическая задача непосредственно корреспондирует со ст. 7 Конституции РФ, в которой российское государство признается социальным, политика которого направлена на создание условий, обеспечивающих достойную жизнь и свободное развитие человека. На основе этого фундаментального конституционного положения муниципальная служба в РФ формируется как социальный институт гражданского общества, призванный обеспечить полное удовлетворение духовных и материальных потребностей населения на местном уровне;

3) обеспечение самостоятельного решения населением вопросов местного значения, включая владение, пользование и распоряжение муниципальной собственностью (см. ч. 1 ст. 130 Конституции РФ). Решение этой задачи, по нашему мнению, предполагает создание в муниципальных образованиях реального организационно-правового механизма решения населением вопросов местного значения путем: 
- разработки в муниципальных правовых актах механизмов реализации законодательных установлений об активизации деятельности всех субъектов местного самоуправления;

- настойчивой и контролируемой населением организаторской деятельности структур муниципальной службы в решении всего комплекса проблем социально-экономического развития территорий муниципальных образований.

Другими стратегическими задачами муниципальной службы, призванной обеспечивать полномочия органов и выборных должностных лиц местного самоуправления, являются:

1) организационно-правовое обеспечение всего управленческого цикла местных органов власти: подготовка, принятие, организация исполнения и контроль за реализацией устава муниципального образования и других муниципальных правовых актов;

2) исполнение на территории муниципалитета Конституции РФ, федерального законодательства, законов соответствующего субъекта федерации, а также отдельных государственных полномочий РФ и субъектов в ее составе, передаваемых органам местного самоуправления. В правотворческом процессе и правоприменительной практике на местном уровне муниципальная служба призвана стоять на защите прав и законных интересов населения муниципального образования, обеспечивая сотрудничество и взаимодействие органов местного самоуправления с государственными органами, предприятиями, учреждениями и организациями, находящимися в муниципальной собственности, а также иными субъектами хозяйственной деятельности, расположенными на территории соответствующих поселений, муниципальных районов и городских округов;

3) обеспечение участия органов местного самоуправления в формировании единой системы оказания государственных и муниципальных услуг с использованием информационно-телекоммуникационной сети Интернет, организация предоставления услуг в многофункциональных центрах по принципу «одного окна», поэтапное улучшение качественных показателей процессов предоставления услуг в электронной форме на основе перехода на реестровую модель предоставления услуг [Головин, Большакова 2018: 154-159].

\section{Список литературы}

Головин Е.Г., Большакова В.М. 2018. Государственные и муниципальные услуги: формирование основ правового регулирования: монография. Н. Новгород: Изд-во НИУ РАНХИГС. 170 с.

\section{CONSTITUTIONAL FRAMEWORK OF THE STRATEGIC OBJECTIVES OF THE MUNICIPAL SERVICE}

Abstract. The article substantiates the strategic tasks of the municipal service in the context of reforming and developing local self-government. The author shows the need to set up the strategic tasks for the apparatus of 